\title{
THE BEST OF BRITISH
}

\section{A Woman in History \\ Eileen Power, 1889-1940 \\ Maxine Berg}

Using letters, diaries and reminiscences, this text recreates the life of the major charismatic British historian. It describes, for the first time, the remarkable intellectual and scholarly achievements that ranked her alongside Tawney, Trevelyan and Toynbee.
40278-6
Hardback
$\$ 69.95$
$56852-8$
Paperback
$\$ 24.95$

\section{Charles Darwin}

The Man and His Influence

\section{Peter J. Bowler}

"Peter Bowler has fulfilled the obligation to explain the significance of Darwin's work to a more general audience, seizing the opportunity to transmit the conclusions of recent scholarship."

-British Journal for the History of

Science

Cambridge Science Biographies

56668-1 Paperback $\$ 15.95$

\section{Charles Daruin's \\ Letters}

A Selection, 1825-1859

\section{Charles Darwin}

\section{Frederick Burkhardt, Editor} Foreword by Stephen Jay Gould

"...no one could possibly match Darwin for fascination and appeal...the wonderfully expressive and richly varied letters of Charles Darwin represent one of the great dramas of western history."

-Stephen Jay Gould

56212-0 Hardback

$\$ 21.95$

\section{Handbook of \\ British Chronology}

Third Edition

\section{E.B. Fryde, D.E. Greenway,}

S. Porter, and I. Roy, Editors

As well as including lists of monarchs, dukes, marquesses and earls, this book details officers of state and archbishops and bishops for the whole of the British Isles from the AngloSaxon period through to 1985 .

Royal Historical Society Guides and Handbooks 2 56350-X Hardback \$49.95

\section{Citizenship and Community}

Liberals, Radicals and Collective Identities in the British Isles, 1865-1931

\section{Eugenio F. Biagini, Editor}

This book explores the links between liberalism, social democracy and nationalism within the framework of traditional republican ideals of "civic virtue" and active citizenship. It focuses attention on the regions of Britain, revealing how different forms of collective identity interacted in popular attitudes to political and social debates.

Contributors: E.F. Biagini, M. Pugh, Pat Thane, J. Coffey, G.I.T. Machin, N. Scotland, J. Spain, A. Howe, F. Trentman, G. Greenlee, C. Fitzpatrick,J. Shaw, R. Lewis, Jose Harris 48035-3 Hardback \$64.95

\section{Gender in Mystical and Occult Thought}

Behmenism and its Development in England B.J. Gibbons

This book argues that Behmenist thought is a neglected aspect of the revision in the moral status of women during the early modern period, contributing significantly to the rise of the Romantic notion of womanhood and "Victorian" sexual ideology.

Cambridge Studies in Early Modern British History

48078-7 Hardback \$54.95

\section{Enlightenment and Religion}

Rational Dissent in Eighteenth-Century Britain

\section{Knud Haakonssen, Editor}

These interdisciplinary essays provide a fresh analysis of rational dissent within English Enlightenment culture from a variety of viewpoints. Its wide perspective and new research make this text an important and original contribution to eighteenth-century studies. Contributors: Knud Haakonssen, Robert K. Webb, M.A. Stewart, Martin Fitzpatrick, David L. Wykes, John Seed, Wilfrid Prest, A.M.C. Waterman, John Gascoigne, Alan Saunders, Alan Tapper, Iain McCalman

Ideas in Context 41

56060-8 Hardback \$59.95 


\section{THE BEST OF BRITISH}

The Boundaries of the State in Modern Britain

\section{S.J.D. Green and}

\section{R.C. Whiting, Editors}

At a time of intense debate about the state, the collection of interdisciplinary studies gathered here emphasizes the sheer variety of public involvement in British life, the ebb and flow of that involvement and its dynamics, and the wider implications this has for civil society and intellectual life.

Contributors: S.J.D. Green, R.C. Whiting, Jose Harris, Michael Bentley, David Marquand, Robert Skidelsky, Roger Middleton, G.C. Peden, Alan Deacon, Anne Digby, Adrian Wooldridge, J.M. Winter, Charles Tounshend, Bryan Wilson, Christie Davies 45537-5 Hardback \$64.95

\section{Relfigion, Literature, and Polftics in Post-Reformation England 1540-1688 Donna B. Hamilton and Richard Strier, Editors}

This book treats English history and culture from the Reformation to the Glorious Revolution as a single coherent period in which religion is a dominant element in political and cultural life.

Contributors: Donna B. Hamilton, Richard Strier, Annabel Patterson, Andrew Hadfield, Debora $K$. Shuger, Lori Anne Ferrell, David Smith, Laura Blair McKnight, Gary D. Hamilton, Helen Wilcox, Mark Goldie, Gary S. De Krey, Steven Pincus 47456-6 Hardback \$54.95

\section{Seizures of the Will in Early Modern English Drama \\ Frank Whigham}

Set in the context of social rank, gender, kinship and service relationships, this text includes detailed and innovative analyses of the following five English Renaissance plays: The Spanish Tragedy; The Duchess of Malfi; Arden of Faversham; The Miseries of Enforced Marriage; and A Yorkshire Tragedy.

Cambridge Studies in Renaissance Literature and Culture 11

$\begin{array}{lll}41877-1 & \text { Hardback } & \$ 54.95 \\ 56449-2 & \text { Paperback } & \$ 19.95\end{array}$

\section{The Factory Question and Industrial England, 1830-1860 \\ Robert Gray}

This engaging study addresses the continuing controversy over industrialization, examining different perceptions of factories and factory work. Using varied sources such as sermons, medical treatises, fictional and visual representations, Gray investigates the role of language in shaping the debate on factor 49659-4 Hardback \$59.95

\section{The Wineteenth-Century Church and English Society \\ Frances Knight}

This is the first study to consider the meaning of Anglicanism for ordinary people in nineteenth-century England. It is concerned equally with the beliefs of lay people and parish clergy, examining Anglicanism both as a supernatural belief system and as part of English society.

45335-6 Hardback \$54.95

\section{After the Famine}

Irish Agriculture, 1850-1914

\section{Michael Turner}

Divided into three parts, this text examines Irish agriculture in the wake of the disastrous famine of the 1840's. It analyzes changing agricultural structures in terms of land use and peasant occupancy; estimates the annual value of Irish output; and assesses Irish agricultural performance in terms of several measures of productivity.

55388-1 Hardback \$54.95

\section{Organised Capital}

Employers' Associations and Industrial Relations in Northern England

\section{Arthur Mclvor}

Using previously untapped primary sources, this book explores employers' organizations from a regional, comparative perspective, analyzing their growth and activities during their heyday, and challenging current interpretations of employers' groups.

55094-7 Hardback \$59.95 


\section{THE BEST OF BRITISH}

\section{Britain, Southeast Asia and the Onset of the Pacific War \\ Nicholas Tarling}

This book describes British policy in Southeast Asia in the early years of World War II.

With its military strength directed against

Germany, Britain drew on diplomatic

resources to maintain its power in the area

and to limit the Japanese threat. The book

focuses on Britain's relations with America,

Dutch India, the Philippines, French Indo-

China and Thailand.

55346-6 Hardback \$64.95

\section{Riches and Poverty}

An Intellectual History of Political

Economy in Britain, 1750-1834

\section{Donald Winch}

The work of Adam Smith provided a key for studying the rich and poor and assessing the American and French revolutions and their aftermath. This text is a compelling narrative of these developments, which emphasizes throughout the moral and political bearings of economic ideas.

Ideas in Context 39

$\begin{array}{lll}\text { 55105-6 } & \text { Hardback } & \$ 64.95 \\ 55920-0 & \text { Paperback } & \$ 22.95\end{array}$

\section{Milton and}

\section{Republicanism}

David Armitage,

Armand Himy, and

Quentin Skinner, Editors

"... deserves a warm welcome for at last bringing Milton studies fully in contact with these developments in the history of political thought."

-Times Literary Supplement

Contributors: David Armitage, Cedric Brown,

Thomas Corns, Tony Davies, Martin Dzelzainis,

Armand Himy, Roger Lejosne, Quentin Skinner,

Nigel Smith, Elizabeth Tuttle, Nicholas von

Maltzabn, Blair Worden

Ideas in Context 35

55178-1 Hardback \$54.95

\section{Now in paperback...}

\section{Commoners: \\ Common Right, Enclosure and Social Change in England, 1700-1820}

\section{J.M. Neeson}

"Commoners.... will transform the understanding of [eighteenth-century] agrarian and social history."

-Customs in Common

"Little can be said in criticism of this wonderful book....Commoners is a major contribution to an emerging view."

-Journal of Economic History

Past and Present Publications

56774-2 Paperback \$24.95

\section{Winner of the} 1994 Allan Sharlin Memorial Prize of the Social Science History Association

\section{Family, Dependence,} and the Origins of the Welfare State Britain and France, 1914-1945

\section{Susan Pedersen}

"Pedersen's work is thorough and persuasive."

-Times Literary Supplement "...this book will long stand as the definitive account of social politics in the two countries during the crucial formative years of their welfare states."

-Contemporary Sociology

55834-4 Paperback $\$ 18.95$
Averilable in baokstoress on fixom AMBRIDGE UNIVERSITY PRESS
40 West 20th Street, N.Y., NY 10011-4211 Call toll-free 800-872-7423.

Web site: http://www.cup.org

MasterCard/VISA accepted. l'rices stabject to clange. 


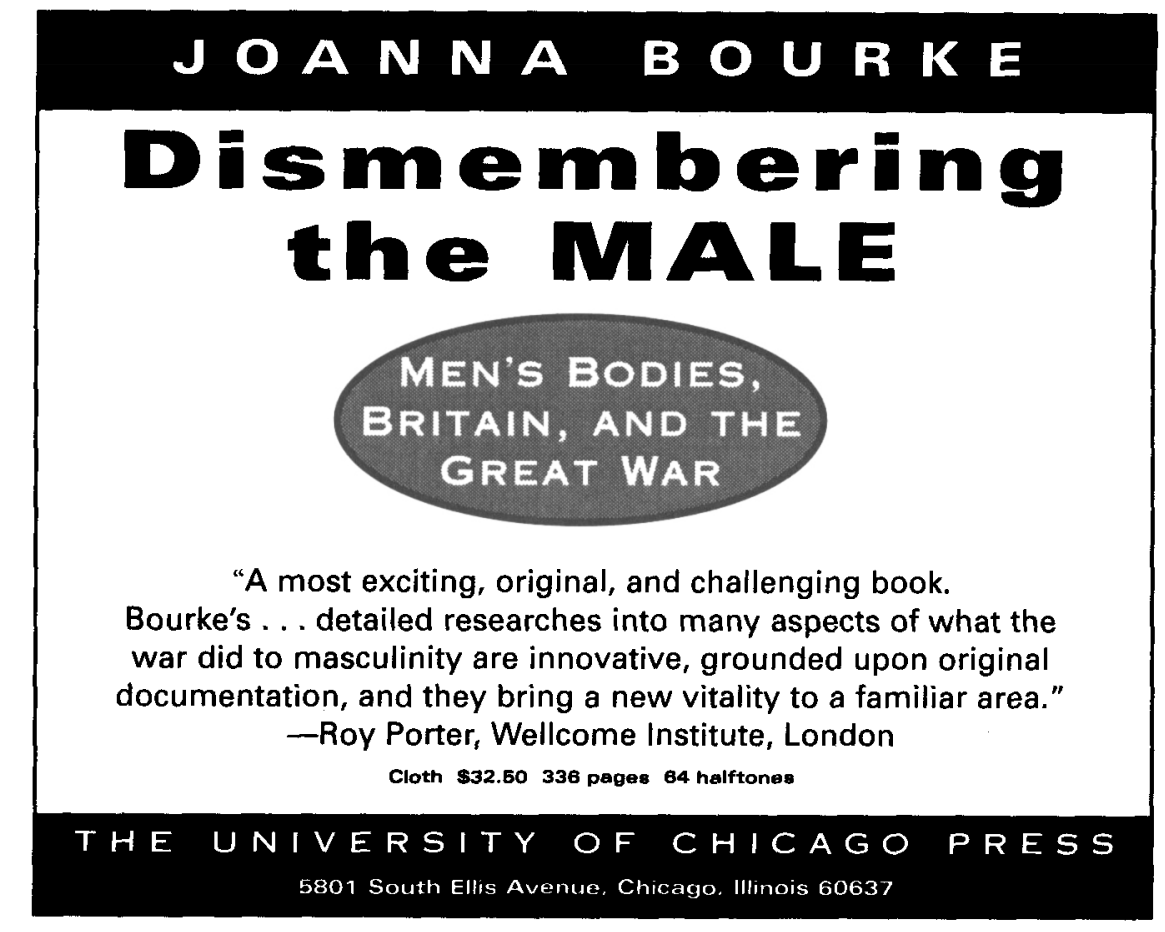

\section{Journal of British Studies}

Sponsored by The North American Conference on British Studies

Editor: Cynthia Herrup, Duke University

Editor-elect: Margot Finn, Emory University

Published quarterly by The University of Chicago Press

Established in 1961, the Journa/ of British Studles has become a major outlet for research on British studies in North America and is devoted to scholarship in areas of British history and culture from the Middle Ages to the present.

In every issue of JBS subscribers will find research and analysis by an impressive roster of international authors, in history, literature, and allied disciplines in the humanities and social sciences, on topics that include social policy, religion, economics, law, demographics, politics, gender, and social and cultural history.

JBS also seeks to expand its coverage with both established and emerging sectors of British studies, including Irish and Anglo-American culture and literature and in the broader experience of colonization and decolonization in the British-speaking world.

Regular one-year subscription rates: Institutions $\$ 77.00$; Individuals $\$ 43.00$; NACBS Individual Members $\$ 29.00$. Outside USA, please add $\$ 2.50$ for postage. Conndians, please also add $7 \%$ GST. Student subscribers accepted as members of the society only. Visa and MasterCard peyments accepted. Credit card custamers may fax their orders to 312/753-0811. To order send check or credit card information (acct. \#, exp. date, telephone number, and signature) to:

\section{The University of Chicago Press} Journals Division, Dept. SS6SA, P.O. Box 37005, Chicago, IL 60637 USA 


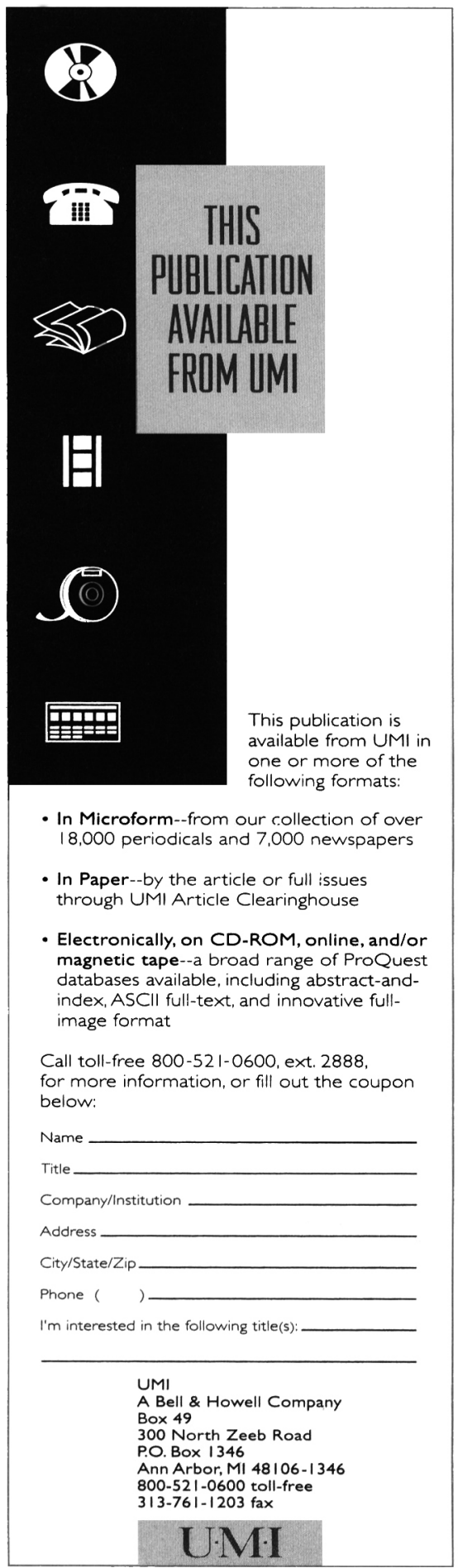

POSTCOLONIAL CRITIQUE

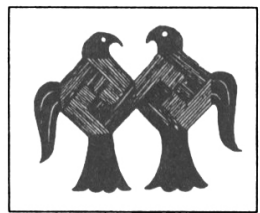

Whose India? The Independence

Struggle in British and Indian

Fiction and History

Teresa Hubel

"Whose India? combines the rigors of solid academic analysis with a fluid and directed style which make it both a pleasure to read and an intellectual treat."

-John L. Hill, Concordia University 256 pages, paper $\$ 16.95$, library cloth edition $\$ 46.95$

A Rule of Property for Bengal: An Essay on the Idea of Permanent Settlement

Ranajit Guha

With a Foreword by Amartya Sen

"Guha's study, still controversial, remains the decisive study of the Permanent Settlement."-Ronald Inden, University of Chicago 280 pages, paper $\$ 17.95$, library cloth edition $\$ 49.95$

Duke University Press Box 90660 Durham, NC 27708-0660

http://www.duke.edu/web/dupress/ 


\section{The Journal of Modern History}

\section{Significant scholarship and important interpretations of European history from 1500 to the present}

John W. Boyer and Julius Kirshner, Editors

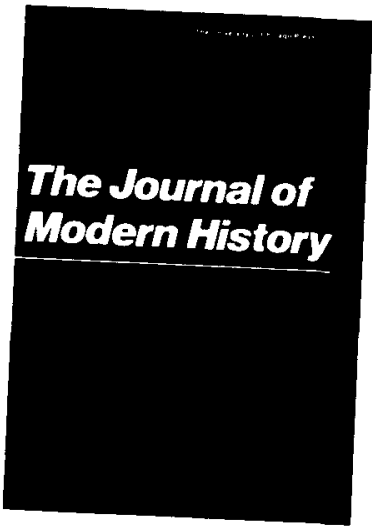

\section{Significant scholarship}

The Journal of Modern History is recognized as the leading American journal for the study of European intellectual, political, and cultural history. The journal's geographical and temporal sweep-the history of the European continent, including Russia and the Balkans, since the Renaissance-makes it unique in its field.

\section{Important interpretations}

Combining traditional and innovative ways of writing history, the $J M H$ devotes special issues to crucial topics and assesses trends and developments in historiography. As the premier reviewing journal for European history, it presents several major review articles and up to sixty shorter reviews each issue. If your research requires the fusion of social, political, intellectual, and economic history, the $\mathbf{J} \boldsymbol{M H}$ will enhance your scholarly work.

One year rates: Individuals $\$ 35.00$; Institutions $\$ 82.00$; AHA Indiv. Members $\$ 27.00$; Students (with copy of ID) $\$ 27.00$. Outside USA add $\$ 7.00$ for postage. Canadians, include $7 \%$ GST. Visa and MasterCard accepted. To subscribe, send check or complete charge card information to The University of Chicago Press, Journals Division, Dept. SS6SA, P.O. Box 37005, Chicago, IL 60637. 


\section{THE ENGLISH HISTORICAL REVIEW}

After 107 continuous years of publication, this leading journal has been increased from four to FIVE issues per year, to meet the challenge of the ever-increasing volume of new research and publications in history today.

The English Historical Review deals not only with

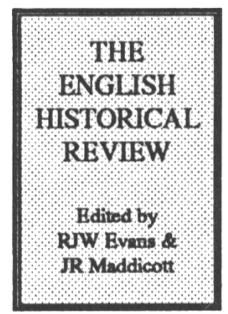
British history, but with almost all aspects of European and world history since the classical era.

With contributions from around the world, each issue includes major Articles, Notes and Documents and Debates on medieval and modern themes. The journal also features an unrivalled range and quantity of reviews of books published worldwide.

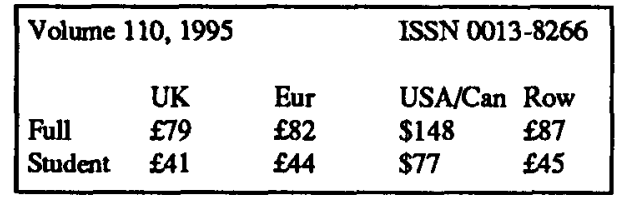

Articles for 1995 include.

The Huns and the End of the Roman Empire in Western Europe Peter Heather

The West Saxon Charters of King Ethelwulf and his Sons Simon Keynes

Richard II and the Vocabulary of Kingship Nigel Saul

Keynes and the German Inflation Niall Ferguson
FREE ISSUE OFFER

$\square$ Please send me a FREE sample issue of The English Historical Review, without obligation to subscribe.

Return to: Julia Wood, Longman Higher Education, Longman House, Bumt Mill, Harlow, Essex CM20 2JE. Tel 01279623212 , Fax 01279 623862, e-mail longhe@cityscape.co.uk
Name

Address

Jnl Mod His

Longman Higher Education 


\section{THE UNIVERSITY OF CHICAGO PRESS}
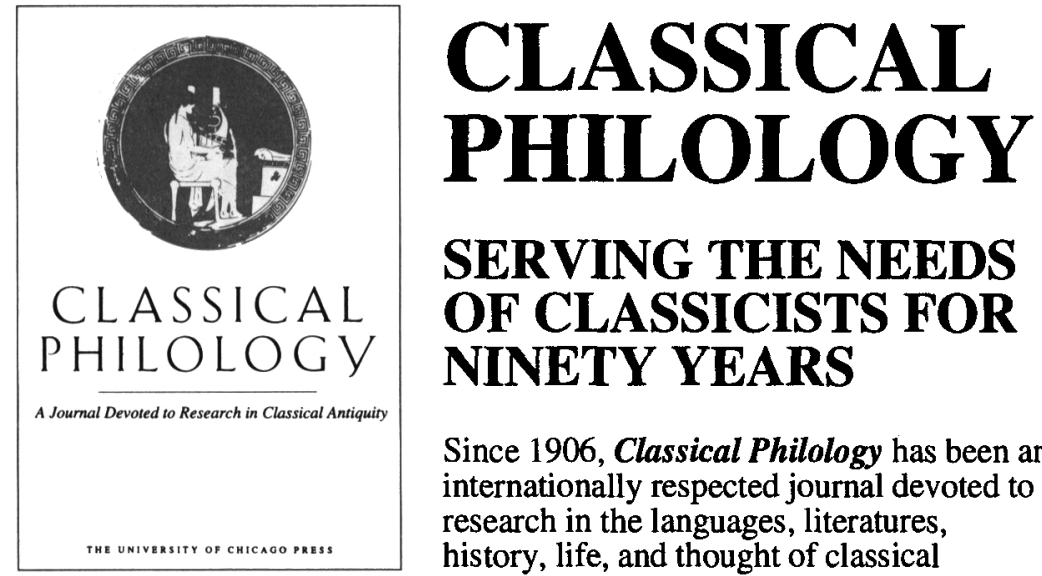

Since 1906, Classical Philology has been an internationally respected journal devoted to research in the languages, literatures, history, life, and thought of classical antiquity. Classical Philology will keep you informed about current debates and points of discussion among classicists, making you part of a lively forum. In addition to major articles, you'll find substantial book reviews in each issue to help you identify works valuable for your research and coursework. Classical Philology publishes the best current research on classical antiquity, applying a variety of interpretive approaches to cover a broad range of topics in essays you'll read again and again for years to come.

Edited by Elizabeth Asmis

Published quarterly by The University of Chicago Press

Regular one-year subscription rates: Individuals $\$ 39.00 ;$ Students \$26.00; Institutions \$95.00.

Outside the USA, add $\$ 5.00$ postage.

Canadians, please add 7\% GST plus postage.

Visa and MasterCard accepted.

To subscribe, send check, purchase order, or complete credit card information to

The University of Chicago Press

Journals Division, Dept. SS6SA, P.O. Box 37005, Chicago, IL 60637 


\section{Gender, Sex, and Subordination in England,} 1500-1800 Anthony Fletcher

"A perceptive analysis of the predication of social order on gender order.... [Fletcher] convincingly demonstrates how it is only by grasping the production of gender categories that the inner logic of society as a whole will be revealed."-Roy Porter, Times Literary Supplement $\$ 37.50$

\section{Absolute Monarchy and the Stuart Constitution} Glenn Burgess

Glenn Burgess here presents a convincing reassessment of the turbulent politics of seventeenth-century England, arguing that it was Charles I's exploitation of agreed prerogatives that led to the polarization between Court and Parliament. $\$ 30.00$

\section{Francis Bacon}

The History of a Character Assassination Nieves Mathews

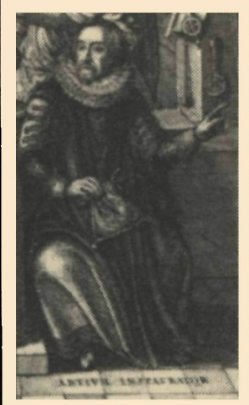

In this fascinating reevaluation of one of Britain's most significant figures, Nieves Mathews examines the charges against Bacon and reveals how distorted facts can be recast as historical truths. $\$ 50.00$

\section{Britain and the Defeat of} Napoleon

1807-1815

Rory Muir

Muir presents a new assessment of the last years of the long war and reveals that the British economy and political system were as essential to victory as military might and tactical brilliance. His comprehensive account shows how politicians, the press, the crown, civilians, soldiers, and commanders together achieved the victory. $\$ 45.00$ A selection of History Book Club

New in paper

\section{The Personal Rule of Charles I}

Kevin Sharpe

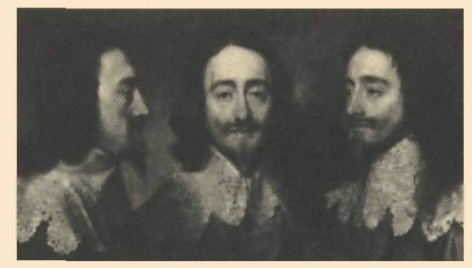

"An impressive book which provides the most intensive scrutiny yet directed at these controversial years. Its evidence will remain an invaluable contribution to Stuart studies."-Ronald Butt, The Times, London $\$ 25.00$

\section{The Rise and Fall of Liberal Government in Victorian Britain Jonathan Parry \\ "A bold, as well as a capable and rewarding book.... [It gives] the period an unusual shape and orienta- tion that deserve close scrutiny." -Michael Bentley, Times Literary Supplement $\$ 20.00$}

\section{Yale University Press}

P.O. Box 209040 $\approx$ New Haven, CT 06520 
